\title{
Toponimul Dorna. Probleme de etimologie și de interferență lingvistică ${ }^{\dagger}$
}

\author{
Dinu Moscal* \\ Departamentul de Cercetare Interdisciplinar - Domeniul Socio-Uman, Universitatea „Alexandru Ioan Cuza”, \\ Str. Lascăr Catargi 54, 700107 Iași, România \\ Institutul de Filologie Română „A. Philippide”, Str. Th. Codrescu 2, 700481 Iași, România
}

\section{Despre articol}

Istoric:

Primit 14 iunie 2016

Acceptat 21 iunie 2016

Publicat 1 august 2016

Cuvinte-cheie:

toponimie

etimologie

contact lingvistic

diacronie

\begin{abstract}
Rezumat
Stabilirea unei etimologii toponimice presupune identificarea modului în care faptele de limbă legate de nume se raportează la realitatea desemnată și la contextul socio-geografic al acesteia. Studiul toponimului Dorna este un caz ce demonstrează că există situații în care cunoașterea realității extralingvistice în plan diacronic devine un argument pentru valabilitatea unei interpretări lingvistice. Analiza toponimelor omonime, a derivatelor și a sintagmelor care conțin acest toponim în raport cu realitatea desemnată și istoricul acesteia indică seriile de toponime cu istoric similar, în cazul de față fiind vorba despre cele cu origine descriptivă și cele cu origine personală. Analiza cîmpului toponimic al hidronimului Dorna (numele afluentului drept principal al Bistriței) pune în evidență schimbările de la nivelul nomenclaturii românești după contactul cu limba germană, prin intrarea sub administrația austriacă în perioada $1774-$ 1918 a aproape întregului ansamblu socio-geografic corespondent acestui cîmp toponimic.
\end{abstract}

\section{Problematica generală}

Multe dintre toponimele cu o vechime mai însemnată devin mărturii pentru realitățile conexe numelui locului, în general legate de istoria sau de geografia zonei, sau cu relevanță în domeniul lingvistic propriu-zis, și anume în probleme de lexic, morfologie, fonetică sau de interferență lingvistică. Dorna este un toponim cu o atestare documentară relativ tîrzie (anul 1568), iar desemnatul în cauză este afluentul drept principal al rîului Bistrița. Etimologia toponimului, adică justificarea raportului dintre semnul lingvistic și realitatea (socio-)geografică desemnată (Moldovanu, 1972, p. 75; cf. și Conea, 1969, p. 246), implică o cercetare prealabilă a naturii sale (apelativ sau nume propriu), care va stabili categoria toponimului (descriptiv sau personal) și a originii sale lingvistice, care va releva etnia denominatorului (toponim românesc sau străin). Pe lîngă acest fapt, toponimul a dezvoltat un cîmp (toponimic) prin polarizări și diferențieri. Polarizarea este definită ca procesul prin care un nume al unei realități dintr-o categorie (socio-)geografică intră în opoziție cu un alt nume, opoziție care reflectă un raport cu o realitate dintr-o altă categorie (socio-)geografică. De exemplu, numele unui sat, devine, prin polarizare, determinantul unei sintagme denominative pentru dealul, pădurea sau altă realitate geografică din apropiere: Glăvănești $\rightarrow$ Dealul Glăvănești(lor) și Pădurea Glăvănești (cf. MDTM). Diferențierea este definită ca procesul prin care un nume al unei realități dintr-o categorie (socio-)geografică intră în opoziție cu un alt nume, opoziție care reflectă un raport cu o realitate din aceeași categorie (socio-)geografică. De exemplu, numele unui afluent este un derivat diminutival de la numele rîului în care se varsă, așa cum este și în cazul analizat aici: Dorna $\rightarrow$ Dornişoara (pentru detalii

${ }^{\dagger}$ Această lucrare a fost realizată în cadrul proiectului Practici de traducere a numelor proprii în scrisul românesc premodern (1780-1830) (PN-II-RU-TE-2014-4-1108), finanțat de Unitatea Executivă pentru Finanțarea Învățământului Superior al Cercetării - Consiliul Național al Cercetării Științifice (UEFISCDI - CNCS).

*Adresă de corespondență: dinumoscal@yahoo.com. 
vezi Moldovanu, 2010, p. 16-20; cf. și Moldovanu, 2014 și 1972). În interiorul acestui cîmp trebuie să se identifice toponimul primar (nucleul cimpului), pentru a se putea stabili etimonul primar, adică semul lingvistic (apelativ sau antroponim) și motivarea raportului dintre acesta şi realitatea (socio-)geografică desemnată. Toponimele rezultate din polarizări sau diferențieri pot fi numite toponime secundare în cîmp, acestea fiind ulterioare constituirii nucleului. Se pare că primul care a intuit necesitatea unei astfel de analize în toponimie este Ion Conea, care o prezintă într-un paragraf destul de scurt și suficient de clar, încît să nu necesite explicaţii.

Una este etimologia unui toponim - și alta, originea lui ca atare (ca toponim). Se face, într-adevăr, de obicei confuzie între etimologia unui toponim (adică originea lui lingvistică), care-i una, și originea aceluiași toponim ca toponim, care e cu totul altceva. Una este, în adevăr, să descoperi etimologia toponimului Vrancea, adică să descoperi cuvîntul (și, bineînțeles, în primul rînd, limba din care acesta provine), care stă la baza lui (aceasta fiind, încă o dată, etimologia) - și alta este să dovedești dacă Vrancea noastră a fost numită aşa după un personaj care a purtat el acest nume mai întîi (acest nume: Vrancea), sau dacă Vrancea a fost numită aşa după o pădure dintre hotarele ei, sau după o apă, sau o localitate, care s-a numit ea singură așa mai înainte, dar și-a extins (i s-a extins) după aceea numele asupra întregii noastre depresiuni carpatice azi aşa-numită (aceasta fiind... originea propriu-zisă a toponimului). Nu e greu de înțeles, însă, că a studia complet un toponim (sau toponimia unei regiuni) înseamnă a o studia din ambele aceste puncte de vedere. (Conea, 1969, p. 246)

Cunoașterea etimologiei primare este un demers important pentru identificarea toponimului de la care s-a configurat cîmpul toponimic. Al doilea obiectiv este analiza evoluției formale a toponimelor ce constituie acest cîmp, în urma intrării sub administraţia Imperiului Habsburgic între anii $1774^{1}-1918$ a aproape întregului ansamblu de realități (socio-)geografice desemnate prin termenii cîmpului toponimic menționat. Atingerea acestor două obiective este decisivă pentru configurarea exactă a cîmpului toponimicprezentat în final一, care trebuie să reflecte evoluţia raporturilor și a formelor tuturor elementelor componente, considerate întotdeauna în contextul lor geografic, istoric și administrativ.

\section{Etimologia toponimului Dorna}

Realitatea cea mai importantă și cu atestarea documentară cea mai veche din ansamblul socio-geografic în care toponimul Dorna a dezvoltat un cîmp este rîul Dorna $(53 \mathrm{~km})$, afluent drept al Bistriței, considerat uneori și confluent al Bistriței Aurii (partea de la izvoare a Bistriței, pînă la confluența cu rîul Dorna). Sub aspect etimologic, este evident că toponimul este descriptiv, deoarece antroponimia românească nu cunoaște un nume de persoană Dorn (e)a, ci doar Durnea, de origine ucraineană, de la care nu se poate justifica, pe teren românesc, deschiderea vocalei tematice $-\dot{u}-$. Ca apelativ românesc, dornă are o semnificație hidronimică, evidențiată în dicționare sau în glosare regionale. În DLR cuvintul apare prezentat astfel:

dórnă s.f. (Ban[at], Olt[enia] și sud-vestul Transilv[aniei]) Bulboană; loc într-un rîu sau într-un lac unde apa este adîncă (și limpede). (Et. nec.).

Faptul că apelativul este înregistrat în graiurile române sud-vestice și că rîul se află în extremitatea nordică a României ar putea fi considerat un impediment pentru premisa unei origini descriptive, însă aria de răspîndire actuală nu poate fi extrapolată momentului în care rîul a primit acest nume. Un plus de informații oferă DELR:

${ }^{1}$ Anul oficial al anexării este 1775, însă anul ocupației este 1774. Cartografierile au apărut în timpul pregătirilor pentru anexarea nordului Moldovei, începînd cu anul 1754 (pentru detalii, vezi Moldovanu, 2005, p. CXXVIII-CXXXIII). 
dórnă s.f. 1. Cădere de apă; loc mai adîncit pe apă format din căderea apei sau din mîncătura apei: [județele] Argeș, Bacău, Brașov, Constanța, Craiova, Dîmbovița, Dolj, Gorj, Hunedoara, Mehedinți, Maramureș, Neamț, Olt, Suceava, Tulcea, Teleorman, Vîlcea, Vaslui. 2. Loc mai adînc în albie unde se scaldă copiii, săpat de apa care se răsucește în cot: [localităţile] Densuş, Lonea, Petrila, Ștei, Totești - [județul] Hunedoara. 3. Bulboană cu vîrtej mare într-o apă curgătoare; cotitură bruscă a apei: [localitățile] Densuș, Hățăgel, Unirea - [județul] Hunedoara. 4. Loc de scaldă cu apă adîncă (de obicei la un cot al apei): [localitatea] Cetatea - [județul] Gorj; [localitățile] Cîmpa, Densuș, Hățăgel, Jieț, Lonea, Peșteana, Sălaşu de Sus, Totești, Tuștea, Unirea - [județul] Hunedoara. 5. Loc adînc în albia unei ape: [localitatea] Timiș - [județul] Brașov. 6. Loc întins și mai lăsat unde se menține apa mai multă vreme: [localitatea] Sălașu de Sus - [județul] Hunedoara. 7. Semn pentru delimitarea pădurilor: [localitatea] Brîncoveni [județul] Olt.

Așadar, conform DELR, aria de răspîndire actuală a apelativului dornă cuprinde, pe lîngă zona sud-vestică, şi o fîșie înspre centrul României, apoi spre nord prin zona de est, fără a cuprinde extremitatea estică, pînă la limita nordică (județele Suceava și Maramureș), la care se adaugă, în mod surprinzător, extremitatea sudestică. Extremitatea nordică a acestei fiş̦ii cuprinde și ansamblul socio-geografic corespondent cîmpului toponimic în discuție. Totuşi, trebuie remarcat faptul că aria de răspîndire a sensului 1 -care în realitate este însăşi întrebarea din chestionarul de anchetă indirectă cu care au lucrat autorii dicționarului, care au notat după întrebare, între paranteze, și termenul dornă-este acoperită de sensurile 2-7 numai pentru zona de sud-est. În ce măsură a influențat notaţia din paranteză răspunsul informatorilor, care ar fi putut s-o preia pur și simplu din paranteza chestionarului, nu se poate verifica, cert este informația din DELR trebuie privită cu rezerve. Coordonatorul DELR nu dă toate aceste detalii în Introducere (Bolocan, 2009, p. 8-9), și nici nu dă vreo explicaţie legată de simpla indicare județelor, aşa cum se întîmplă la sensul 1. Informații suplimentare apar în DTRO (II, s.v.), de unde aflăm că județele Brașov, Covasna, Dîmbovița, Galați, Tulcea, Teleorman și Vaslui sînt reprezentate prin cîte o singură localitate, iar județele Argeș, Neamț și Vîlcea prin cîte două localități. Autorii nu fac cunoscut modul în care au fost selectați informatorii, însă este foarte probabil ca aceștia să fi fost cadre didactice din localitățile respective. La aceste observații se mai adaugă un amănunt legat de DELR: „Vom trata și acele entopice pe care le vom extrage din toponime, färă ca să le avem înregistrate pînă în momentul de față undeva, ca apelative" (Bolocan, 2009, p. 9, s.n.). Toate aceste detalii pun sub semnul întrebării veridicitatea limitelor ariei de răspîndire indicată în DELR. Conea afirma că termenul nu mai circula acum aproape o jumătate de veac în regiunea Tismanei, chiar dacă partea montană a rîului Tismana se numește și Dorna (Conea \& Bugă, 1971, p. 93). Cu atît mai mult este suspectă prezența termenului în afara zonelor indicate în DLR. Eremia nu întîlnește acest termen în anchetele sale din Basarabia și zonele locuite de români din Ucraina, făcute în perioada 1968-2004 (DTG). Iordan (1963, p. 510) afirmă că „acest apelativ trebuie să fi existînd (ori, cel puțin, să fi existat) și prin Moldova, cum arată toponimicele citate, care sînt răspîndite numai pe teritoriu lingvistic moldovenesc", chiar dacă are în vedere și toponime care nu pot fi explicate prin apelativul dornă-adică Movila Dornei şi Dorneştii-sau care nu se raportează direct la acesta, adică Dornenii și ignoră prezența toponimului în afara teritoriului Moldovei (vezi infra).

Trebuie menționat și faptul că apelativul dornă prezintă și două derivate: (a) dorni și durnişcă.

dorní vb. IV. Intranz. (Prin nordul Olt[eniei] și sud-vestul Transilv[aniei]; despre apa unui rîu sau a unui lac) A forma o dornă. (De la dornă). (DLR)

durníșcă s.f. Locul unde se revarsă un rîu: [localitatea] Pungești - [județul] Vaslui. (DELR)

Înregistrarea sensului de 'bulboană, villtoare' în toată aria de răspîndire, precum și existența celor două derivate ne indică faptul că semnificația apelativului dornă este stabilă și elimină posibilitatea ca dornă să fie un apelativ posttoponimic. Sensurile 'cădere de apă’ și 'cotitură bruscă a apei' din DELR (de la sensul 
1 și sensul 3) a apelativului dornă reprezintă un simplu caz de metonimie prin contiguitate (în realitatea fizică este un raport cauză-efect), iar sensul 4 este o extensie. Sensul 7, cu o singură prezență, este foarte probabil o confuzie cu apelativul bornă a informatorului. Sensul 6 pare să fie o extensie. Pentru sensul general pledează şi alte surse, tot pentru graiurile române sud-vestice: „adîncitură de rîu” (SD), „vîrtej de apă, bulboană” (CADE), „vîltoare, loc unde apa e mai adîncă” (Suflețel, 1983, p. 264), „iar unde apa e învolbată și înspumată și adîncă, acolo îi spuńem dornă" (Conea, 2010, p. 135).

Stabilitatea semantică a apelativului este importantă pentru stabilirea motivației toponimice. Originea unui hidronim descriptiv poate fi o caracteristică a cursului de apă sau un reper prin care se identifică, acesta fiind situat, de obicei, la izvoare sau la vărsare. La izvoarele rîului Dorna, în partea dinspre est, se află Piatra Dornei-percepută ca fiind locul de unde izvorăște Dorna „și apoi apa Dornii în sus pănă în obărșie de supt Piatra Dorni” (BĂLAN, D.C. 31, document din anul 1755). Aspectul genitival al sintagmei indică un raport de contiguitate, fie între stîncă (Piatra Dornei) și o realitate geografică din apropiere, avînd caracteristicile unei dorne, fie între stîncă şi un toponim Dorna, desemnînd o apă curgătoare. Prima posibilitate este infirmată de contextul geografic al stîncii, în timp ce a doua este confirmată de prezența în imediata apropiere a rîului Dorna.

Chiar dacă este nerelevată sub aspect toponimic, etimologia entopicului dornă poate prezenta interes, pentru că ar putea indica sensul principal, preluat din etimon. $O$ încercare de etimologie are Densusianu:

dornă „vîrtej de apă, bulboană”, din tema dor - cu înțelesul de 'a smulge, a despărți'; comp. v.pol. dura (= dora) 'spărtură, gaură' și slov. predora 'loc inundat' (pentru formațiune, comp. v.bulg. vlüna 'val'). Numele rîului Dorna e desigur același cuvînt. (Densusianu, 1915, p. 57)

Soluția dată de Densusianu nu a fost acceptată (cf. DLR). Iordan (1963, p. 510) afirmă în mod greșit că Bogrea (1922, p. 799) ar fi acceptat etimologia lui Densusianu. Aceasta este problematică atît în privința radicalului, dar mai ales a sufixului slav $-n a(<-\check{\text { nna }})$, un sufix denominal care formează adjective posesive (Miklosich, 1927, p. 211 [95]; cf. și Petrovici, 1960, p. 55; 1970, p. 160).

Prin urmare, etimologia hidronimului Dorna (afluent drept principal al rîului Bistrița) ar trebui să indice un raport între semnificația apelativului „bulboană; loc într-un rîu sau într-un lac unde apa este adîncă” și o realitate care prezintă aceste caracteristici. Nu poate fil luată în considerare etimologia propusă de Weigand pentru acest hidronim-din rut. dorna zemlja 'frisch gerodetes Land' [= pămînt recent defrișat] —, aceasta fiind contestată de Bogrea (1922, p. 798-799), tocmai prin trimiterea la apelativul dornă. Un loc cu caracteristicile corespondente semnificației apelativului dornă, care să aibă funcția de identificare a întregului curs al rîului Dorna, nu apare în zona izvoarelor, ci chiar la vărsarea în Bistrița, aici formîndu-se o dornă, descrisă în termeni geografici, după cum urmează:

De la vărsarea Dornei spre est [...] apa Bistriței face aici un cot aproape in loc, urmat de un al doilea mai la vale. Pereții văii actuale, drepți și rupți, care corespund stratelor ridicate vertical, tapșanurile aluviale de la convexități și liniştea uimitoare, ca de lac, a rîului, alături de arculstrîns al coturilor, ne dă dreptul să considerăm acest segment al văii Bistriței ca un bun exemplu de meandre adîncite în masa cristalină. (Mihăilescu, 1944, p. 343, s.n.)

Această descriere a locului de la vărsarea Dornei în Bistrița corespunde în întregime semnificaţiei apelativului, ceea ce confirmă ipoteza că hidronimul Dorna este toponimul primar, de la care s-a format întregul cîmp. Alte hidronime sînt un argument suplimentar pentru categoria toponimică descriptivă:

Dorna Mare Groapă mare în Valea Fărășeștiului, s. Fărășești - Timişoara. (DTB)

Dorna, topic în regiunea Clopotivei și porţiune a rîului Tismana, aproape de mănăstire [= Mănăstirea Tismana] (vezi Conea, 1936, p. 114). Tot Dorna se numește și partea cea mai adîncă a Jiului, lîngă V[aidei, com. Stănești, jud. Gorj]. (Suflețel, 1983, p. 264) 
Dornă se cheamă, prin partea locului, ceea ce în alte părți se cheamă vîltoare: loc unde apa e mai adîncă și liniștită, pe la coturi. Dornă - numele propriu - se cheamă pe partea cealaltă a Carpaților, rîul Tismana - de la isvor și pînă la Mănăstire. (Conea, 1936, p. 114)

Partea dinspre izvoare a rîului Tismana (afluent drept al Jiului), cea din amonte de Mănăstirea Tismana, cuprinde mai multe cascade, care, desigur, formează adîncituri în rîu, care, în trecut, trebuie să fi fost numite de către localnici dorne. În acest sens, se poate adăuga încă o referire a lui Conea la cursul superior al Tismanei, adică la partea montană propriu-zisă a rîului:

Rîul Tismana, cît timp (partea care) curge prin munți, se numește Dorna. Apelativul de bazădorna-nu mai e, însă, viu în regiune. În schimb, e încă viu dincolo de munți, în Țara Hațegului, unde Ov. Densusianu [1915, p. 316] spune că înseamnă „vîrtej de apă, bulboană”, deci... apă adîncă. (Conea \& Bugă, 1971, p. 93)

Mănăstirea este construită chiar lîngă o cascadă, amănunt inclus și în legenda etiologică. Etimologia hidronimului Dorna este cu siguranță legată de această caracteristică a cursului superior al Tismanei, probabil chiar de dorna din imediata apropiere a Mănăstirii Tismana. Un argument suplimentar poate fi considerat şi denumirea de Cascade pentru aceeaşi zonă a Tismanei: „Puntea peste rîul Tismana era dincoace de Cascade” (Ștefulescu, 1909, p. 73), puntea fiind lîngă Mănăstirea Tismana. DTRO înregistrează în satul Tismana cuvîntul dornă cu semnificația „izvor”, care reprezintă cu siguranță un caz de resemantizare, în dorna de lîngă Mănăstirea Tismanei revărsîndu-se un izvor ce iese chiar din stînca pe care este zidită mănăstirea. Toponimul Dorna Verde, consemnat în aceeași lucrare, cu laconica explicație „cascadă”, este un alt caz de metonimie (cf. observațiile la sensul 3 din DELR).

Există însă cîteva sintagme toponimice și cîteva derivate în cazul cărora nu pot fi găsite confirmări pentru aceeași etimologie toponimică. Este vorba despre Movila Dornei, movilă situată la est de satul Munteni (comuna Belcești, județul Iași), Prisaca Dornei (sat, comuna Vama, județul Suceava) și oicoimul Dorneni desemnînd două sate din județul Bacău (unul în comuna Plopana, celălalt în comuna Vultureni). Acestea sînt asociate de Iordan (1963, p. 510) cu hidronimul Dorna, fiind considerate a avea aceeași etimologie (lingvistică).

În ceea ce privește oronimul Movila Dornei, trebuie menționat faptul că apelativul dornă nu este înregistrat în județul Iași. În ATLAS MOLD., în afară de oronimul amintit-însă cu determinantul în nominativ, Movila Dorna - apar și Dealul Dorna (al cărui vîrf este Movila Dorna) și Valea Dornei (mic afluent stîng al Văii Buhna, bazinul Bahluiului). Aspectul Văii Dornei sau al Văii Buhna, în care se varsă, nu oferă vreun argument în favoarea unui raport cu apelativul dornă, iar Movila Dornei și Dealul Dorna nu pot fi puse în raport direct cu apelativul dornă. Însă cîmpul toponimic nu se reduce la aceste trei toponime. În harta lui Bawr de la 1774 apare notat numele unei odăi ca Chutordurnoi (TTRM, I, p. 754/2), tradus „Odaia Dornei” (la fel și Mircea Ciubotaru în Adumitroaei \& Ciubotaru, 2013, p. XIV). Fiind vorba despre un raport de proprietate, proprietarul nu era vreo mănăstire din regiunea Dornei (nici nu exista una atunci), încît să fie vorba de o sintagmă redusă *Odaia (Mănăstirii) Dorna, ci era o persoană, al cărei nume se regăsește în notația lui Bawr Chutordurnoi, adică Durnea, iar sintagma trebuie tradusă prin „Odaia Durnii”. Probabil tot numele proprietarului este etimonul și pentru Movila Dornei și Valea Dornei, același Durnea fiind proprietar al imașului identificat prin această movilă. Situația este similară cu cea a oronimului Movila Durnei (movilă situată la vest de satul Dornești, comuna Costişa, județul Neamț, atestată documentar în anul 1583, DRH, A, VII, p. 574) și cu cea a oiconimului Dorneşti (sat, comuna Dornești, județul Suceava, cu atestare documentară în 1475, în forma Durneştii, DRH, A, II, p. 299), a căror etimologie ne este înlesnită de documentele istorice, în care sînt menționați urmașii săi. În ceea ce privește primul caz, printr-un document de la 1623 nepoții Durnii vînd o casă din Durnești (DRH, A, XVIII, p. 73), iar la 1627-1628, Ioana, nepoata Durnii, vinde partea sa din Durnești (DRH, A, XIX, p. 318). Prima atestare în care $-u$ - tematic este înlocuit cu -o- apare într-un document al administraţiei austriece din 1790 (germ. Dornesty). Cauza înlocuirii este confuzia între vocalele $o$ și $u$, prezentă adesea 
în transcrierile austriece (cf. Moldovanu, 2005, p. CXXXI/1). În cazul celuilalt oiconim, Dorneşti, este vorba despre o analogie cu Dorna (pentru detalii, vezi MDTM, Durnea și Dorneștii ${ }^{2}$ ).

Prisaca Dornei, sat menționat pentru prima dată în 1808 cu numele de Eisenau „Valea Fierului” (colonie de țipțeri), apoi cu numele Prisaca la 1896, apare cu numele actual, Prisaca Dornei, la 1943 (vezi TTRM, I2, p. 945/2). Încercarea de a pune determinantul din sintagma toponimică în raport cu o dornă de pe rîul Moldova, care curge în imediata apropiere, ar putea fi o soluție, însă problematică, deoarece aspectul cursului rîului nu oferă vreun argument în această privință. Conform documentelor administrative, determinantul în genitiv Dornei este adăugat după mult timp oiconimului primar (Prisaca), care se regăsește în sintagmă, iar un alt toponim de la care să se revendice acest determinant nu apare în zonă. Din punct de vedere strict lingvistic, sintagma toponimică este greu de explicat și din cauza circulației foarte restrînse, și numai la nivel popular a apelativului dornă, dacă s-ar considera că acesta mai circula. Într-un mod cu totul excepțional, determinantul din sintagma toponimică Prisaca Dornei nu provine de la o realitate geografică din apropiere, aşa cum întîmplă în mod natural, ci de la o realitate geografică îndepărtată, originea determinantului fiind oiconimul Dorna, varianta populară pentru Vatra Dornei. După tradiția locală, conform informațiilor din ancheta directă făcută de Dragoș Moldovanu, este vorba despre un toponim oficial, sugerat de poziția satului pe calea ferată spre Dorna, prin care să se realizeze o diferețiere față de alte sate din Moldova numite Prisaca.

Cele două sate numite Dorneni, menționate mai sus, au același etimon, adică patrionimul dorneni, fapt confirmat de explicația dată pentru numele satului din comuna Vultureni: „se numește astfel, pentru că locuitorii ei [ai mahalalei Dorneni] sint veniți de la Dorna” (MDG, III, p. 197/3).

Analiza posibilităților etimologice pentru hidronimul Dorna (afluent drept al Bistriței), dar și pentru celelalte toponime susceptibile de a avea o etimologie similară, indică cu certitudine ca etimon apelativul dornă 'bulboană, vîltoare', fapt verificat atît prin realitatea geografică corespondentă pentru toponimele descriptive (geografice), cît și prin etimologiile diferite pentru alte toponime susceptibile de a intra în aceeași categorie, cele mai apropiate fiind descriptivele numite «sociale», cu etimologia provenită dintrun patrionim (Dornenii).

\section{Probleme de interferență lingvistică}

Interferența lingvistică la nivelul toponimiei este un fapt comun. Elementele cîmpului toponimic dezvoltat de hidronimul Dorna apar, desigur, în diverse surse în limbi străine, ca în cazul majorității toponimelor cu o oarecare importanță socio-geografică. Aici va fi însă analizată evoluția acestora în urma intrării sub administrația austriacă, o dată cu anexarea Basarabiei de către Imperiul Habsburgic, precum și modul în care cîteva dintre acestea au fost adaptate sistemului limbii române, păstrînd trăsături nespecifice limbii române, uneori chiar contrare structurilor normale ale toponimelor românești. Spre deosebire de simpla apariție a toponimelor în documente redactate într-o limbă străină, intrarea unei regiuni sub o administrație străină implică nu doar simple adaptări ortografice, cauzate de perceperea aproximativă a nomenclaturii românești, ci și adaptări la sistemul lingvistic german sau la noul sistem administrativ, ceea ce a condus la structuri denominative noi. Cîmpul toponimic dezvoltat de hidronimul Dorna este un caz ilustrativ, prin complexitatea și situațiile rare, chiar inedite, în transpunerea lor în limba germană și adaptarea lor la noul sistem administrativ, precum și în reromânizarea lor după 1918.

Semicalcurile, fenomen general în cazul sintagmelor toponimice, se caracterizează, în principiu, prin traducerea entopicului, la care se adaugă probleme de adaptare fonetică a determinantului din sintagma toponimică și, fiind vorba despre limba germană, antepunerea determinantului. Astfel, hidronimul Rîul

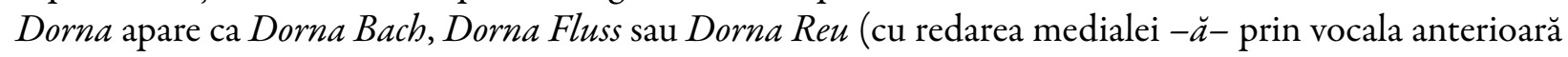
-e- în entopic), iar Runcul Dornei ca Dornj Runkut. Cînd entopicul nu este tradus, topica sintagmei se poate păstra, așa cum este cazul pentru Munceii Dornei, oronim atestat în germană doar în forma Muntsei Dornei (cu redarea grafică a africatei alveolare - ț- prin -ts-), pentru Obcina Dornenilor atestat ca Obczina Dornyenilor, Obsina Dornyenilor (cu redarea grafică a africatei prepalatale surde $-\hat{c}-$ prin $-c z i-s, i-s i-s, i$ 
cu redarea palatalizării consoanei $n$ urmată de $e$ prin $-y e-)$, sau primele atestări pentru Piatra Dornei în forma Piatra Dorni (prin sudiferențiere fonologică, adică prin nesesizarea lui - $\breve{\imath}$-asilabic, cu funcția de morfem, din desinența de genitiv -ǐ̌), Piatra Dorniluj (prin confuzia articolelor -lor / -lui) sau Pietrille Dorni.

O situație diferită pare să fie în cazul oiconimelor, care, integrate într-un nou sistem administrativ, intră în compuse paratactice, care reflectă un raport inversat faţă de nomenclatura administrativă românească. În afară de exemplele de mai sus, adaptările normale la topica limbii germane apar și în structuri juxtapuse în care în poziția determinatului nu este un entopic, ca în Dorna Bach, de exemplu, a cărui topică nu poate crea confuzii în interpretare. Este vorba despre structurile paratactice în care determinantul (antepus) reprezintă «reședința de sat» în percepția administrației austriece. Astfel, părțile satului Dorna și cătunele din apropiere, neînregistrate în nomenclatura oficială înainte de momentul anexării Bucovinei, și anume Vatra Satului, Candrenii, Josenii, Arşița, Chilia, Popenii, Poiana (azi Poiana Negrii) devin: DornaVatra Satului (apoi Dorna-Vatra), Dorna-Candreni, Dorna-Joseni, Dorna-Arșița, Dorna-Chilia, DornaPopeni, Dorna-Poiana, desigur, cu adaptările grafice și erorile inerente. Părțile satului Dorna și cătunele din apropiere capătă astfel o identitate administrativă, însă nu și independență, ele rămînînd cu statutul de părți ale localității Dorna, așa cum arată și Werenka, referindu-se chiar la începuturile administrației austriece:

Dorna $=$ Dorf aus mehreren zerstreuten Häusergruppen bestehend, die verschiedenen Namen führten: Dorna Arschiza, - din jos stînei, - Candreni, - la popeni, - Vatra satului, Dorna $[$ Dorna $=$ Sat alcătuit din mai multe cătune risipite, care aveau nume diferite: Dorna Arșița, - din Josul Stînei, - Candreni, - la Popeni, - Vatra Satului, Dorna].

Watra Dornei $=$ Vatra Dornei (rom.), ebenso die Benennungen: Dorna Arşiţa, Dorna din jos stînei, Dorna Candreni, Dorna la popeni, Dorna vatra satului waren Häusergruppen, die zu Dorna gezählt wurden” [Watra Dornei = Vatra Dornei, și denumirile: Dorna Arșița, Dorna din Josul Stînei, Dorna Candreni, Dorna la Popeni, Dorna Vatra Satului erau cătune, care țineau de Dorna]. (Werenka, 1895, p. 25, 114)

Compusele paratactice impuse de administrația austrică reflectă topica limbii germane, determinantul fiind antepus, astfel că problematizarea acestei terminologii din perspectiva sistemului denominativ popular românesc nu este relevantă (cf. Moldovanu, 1991, p. XLIII; vezi și Prisacaru, 2015, p. 77-78). Interpretarea lor ca fiind „constelații de sate” (Moldovanu, 1991, p. XLIII) este rezultatul unei abordări prospective în cazul de față, multe dintre ele fiind inițial, așa cum reiese din documentele vremii, părți de sat sau cătune, o parte dintre acestea devenind în timp sate de sine stătătoare. Astfel de structuri paratactice sînt aplicate de obicei oiconimelor, dar nu se limitează la oiconime, așa cum se poate lesne observa și din sintagmele toponimice germane corespondente hidronimului Negrişoara: Dorna Niagrischora Bach, Dorna Nyegrisora sau, chiar și cu entopicul netradus, Dornaniegrisoara $R[e u]$ (TTRM, $\mathrm{I}_{4}$, p. 178/1).

Trebuie menționat aici că Dorna-Arini este un oiconim compus, la fel ca şi sinonimul său DornaŞarul, deci nu sînt creații identice, și nici analogice, ci reflectă o contopire a două sate rămase în interiorul graniţelor Moldovei după 1774 (pentru detalii, vezi TTRM, I1, p. 366/2-367/1).

Constituit în jurul nucleului Dorna, cîmpul toponimic german nu s-a menținut multă vreme, ci a dispărut progresiv prin înglobarea localităţilor componente (unele după ce și-au schimbat numele) pînă la desprinderea Bucovinei de Imperiul Habsburgic. Singura care rezistat a fost Dorna-Candreni, al cărei nume a fost greșit românizat la 1919, în forma Dorna Candrenilor, deși o bună înțelegere a compusului ar fi impus o inversare a raportului de determinare: Candrenii Dornei. Un caz similar, însă doar temporar, este cel al sinonimului pentru Dorna-Arini, și anume compusul care indică poziția geografică, Dorna-Gura Negrii, care apare în sintagma Dorna Gurii Negre (cf. și Moldovanu, 2010, p. 303).

Așadar, interferența lingvistică nu a condus doar la obișnuitele probleme de grafie, de morfo-sintaxă și de calc sau semicalc, ci și la distorsiuni în cadrul sistemului denominativ românesc prin împrumutul de 
structuri și prin interpretarea greșită a acestora, cu toate că nu poate fi vorba despre necunoașterea realităților socio-geografice corespunzătoare. În prezentarea detaliată a cîmpului toponimic al hidronimului Dorna sînt precizate toate procesele care au dus la constituirea lui, precum și variantele existente, însă fără a insista asupra situației administrative a localităților denominate. Aceasta poate fi urmărită pe baza trimiterilor la TTRM, $\mathrm{I}_{1-2}$.

\section{Cîmpul toponimic al hidronimului Dorna}

Toate procesele discutate în subsecțiunea anterioară, dar și rezultatul demersului privind etimologia toponimului Dorna (numele afluentului drept al Bistriței) sînt prezentate în cadrul schemei lexicografice a cîmpului toponimic dezvoltat de acesta. Sursele documentare, neprecizate în subsecțiunea anterioară, sînt indicate aici, însă reduse la prima atestare a formei indicate. Toponimele care nu fac parte din cîmp sînt redate spațiat. Avînd în vedere caracterul lexicografic al prezentării cîmpului dezvoltat de hidronimul Dorna, s-au folosit abrevierile din finalul articolului.

DÓRNA top. descr. A. Hidron. (Cu ent. subînțeles) Mare afl. dr. al r. Bistrița (la or. Vatra Dornei, j. Suceava) tTRM, I 3 , 42/2 (a. 1641). $\diamond$ În sint.: Apa Dornei BăLAN, D.c. 31 (a. 1755) sau, cu determ. în nom., Pîrîul Dorna GRĂmadă, T. II, 527 (a. 1783) gRĂMADĂ, T. I, 261 (a. 1937). $\diamond$ În opoz. echipol. cu Dornişoara „Dorna Mică”: Rîul Dorna Mare TTRM, $\mathrm{I}_{4}, 77 / 2$ (a. 1775). S Semicalcuri cu ent. uneori abrev.: germ. Dorna Bach ib. (a. 1774) sau Dorna Fl[uss] ib. (a. 1775), Dorna Mare Fl[uss] ib. (a. 1775); lat. Dorna Fluvius HURM. $\mathrm{XV}_{1}, 631$ (a. 1568) sau Dorna R[ivus] TTRM, $\mathrm{I}_{4}, 77 / 2$ (a. 1788?).

I. P. dife r. Hidron. (În sint. Gura Rîului Dorna) Partea de la vărsare a r. Dorna. DRH, A, XX, 331 (a. 1630, după trad. rus. din 1841). $\diamond$ Prin reducerea sint.: Gura Dornei ib. VII, 726 (fals datat 1584, după slv.), MDG, III, 195/3 (a. 1900).

1. P. pola r. Oicon. (Cu ent. sat subînțeles, în sint.) Gura Dornei [At. la 1640: TTRM, I3 ,43/1.] (Vechi) Vatra Dornei (IX.1).

II. P. d i fe r. Hidron. (Der.; în opoz. privativă cu Dorna A: Dornişoara) Afl. st. principal al r. Dorna (la s. Poiana Ștampei, com. Poiana Ștampei, j. Suceava). TTRM, I $\mathrm{I}_{4}, 78 / 2$ (a. 1774). $\diamond$ În sint.: Pîrîul Dornişoara GRĂMADĂ, T. II, 394 (sec. XIX) sau, cu schimb. de ent. și de caz, Cracul Dornişoarei ib. (a. 1937).

Semicalcuri germ.: Dornischora Bach TTRM, I4, 78/2 (a. 1789); Dorniszora Bach ib. (a. 1775).

1. P. pola r. Fiton. (În sint. Pădurea Dornişoara) Păd. pe ambele părți ale p. Dornișoara. GRăMadă, T. II, 394 (a. 1937).

III. P. sin t. Hidron. Cele două ape curgătoare considerate împreună: Pîrîul Dornelor GABOR, D. 90 (a. 1995).

1. P. pola r. Cremnon. (În sint.; geogr.: Depresiunea Dornelor) Depresiune intramontană ce cuprinde bazinul Dornelor. Săndulache, B. 158 (a. 2009). $\diamond \mathrm{Cu}$ schimb. de ent.; neofic.: Țara Dornelor MIHĂILESCU, D. 335 (a. 1944).

IV. P. pola r. Oron. (În sint. Piatra Dornei) Mt. situat în zona dintre izv. r. Dorna și izv. p. Negrișoara. BĂLAN, D.C. 31 (a. 1755). $\diamond$ Cu ent. în nom.: Piatra Dorna TTRM, I 4 , 77/2 (a. 1788). $\diamond$ Cu ent. la pl.: Pietrele Dornei ib. (a. 1775).

1. P. conf. Oicon. Piatra Dornei [At. la 1778: ib. 78/1.] (Vechi) Vatra Dornei (IX.1).

V. P. pola r. Oron. (În sint. Runcul Dornei $\left.{ }^{1}\right)$ Mt. situat între r. Dorna și p. Dornişoara, în apropiere de izv., la V de s. Dornişoara. GRĂMADĂ, T. II, 506 (a. 1768). $\diamond \mathrm{Cu}$ schimb. de ent. și cu determ. în nom.: Vîrful Dorna HARTA MIL. (a. 1962). $\diamond$ Cu ent. în funcție oron.; în sint.: Vîrful Runcul CHIRIȚĂ, D. 83 (a. 2003, harta). $\diamond$ Cu elipsa determ.: Runcul TTRM, I4,77/2 (a. 1775, germ.). $\diamond$ Semicalc lat.: Mons Dorna ib. (a. 1780).

VI. P. pola r. Oron. (În sint. Munceii Dornei) Munți situați între r. Dorna și p. Negrișoara (afl. dr. al r. Dorna), la SV de or. Vatra Dornei. ib. (a. 1775).

VII. P. p ol a r. Oron. (În sint.; rar: Munții Dornei) Munții Bistriței. MDG, III, 643/2 (a. 1900). 
VIII. P. pol a r. Hidron. (După germ.; în comp. paratactic: Dorna Negrişoara) Negrișoara, afl. dr. al r. Dorna, prin difer. omon. de alte hidronime Negrişoara din bazinul Bistriței. TTRM, I4, 178/1 (a. 1775). $\checkmark \mathrm{Cu}$ ent. postpus în sint.; după germ.: Dornaniegrisoara $R[\hat{\imath} u]$ ib. (a. 1788). $\downarrow$ Semicalcuri germ.: Dorna Niagrischora Bach ib. (a. 1789).

IX. P. pola r. Oicon. (Cu ent. subînțeles) Dorna ${ }^{1}$ [At. la 1568: TTRM, I3, 43/1.] (Vechi) S. la confl. Dornei cu Bistrița; p. restr. componenta principală a s. Dorna (IX.1). $\diamond \mathrm{Cu}$ schimb. de ent.: Tîrgul Dorna TTRM, $I_{2}, 1285 / 1$ (a. 1896). $\diamond$ În sint. cu determ. adj., indicînd provincia istorică: Dorna Bucovineană MDG, III, 195/2 (a. 1900).

1. P. dife r. Oicon. (Precedat de ent., în sint.) Vatra Satului Dorna [At. la 1774: TTRM, $\mathrm{I}_{2}, 1284 / 2$.] Localit. compon. principală a or. Vatra Dornei; (vechi) Dorna (IX), Piatra Dornei (IV.1). $\diamond$ Prin reducerea sint.: Vatra Dornei ib. $\mathrm{I}_{2}, 1285 / 1$ (a. 1823). $\diamond$ Cu determ. în nom., după germ.: Vatra Dorna ib. (a. 1790). $\diamond$ În comp., cu inversarea termenilor, după germ.: Dorna-Vatra MDG, III, 196/1 (a. 1900).

2. P. difer. Oicon. (Germ., în comp.) Dorna-Candreni [At. la 1778: TTRM, $\mathrm{II}_{1}, 73 / 2$.] S. Candreni (considerat localit. compon. a s. Dorna IX), com. Dorna Candrenilor, j. Suceava. $\diamond$ Art.: DornaCandrenii ib. $\mathrm{I}_{1}, 367 / 1$ (a. 1824). $\diamond$ Rom., cu transformarea comp. germ. în sint.: Candrenii Dornei ib. (a. 1793). $\diamond \mathrm{Cu}$ inversarea compon., după germ.; ofic.: Dorna Candrenilor ib. (a. 1899).

a. P. pol a r. Fiton. (În sint. Pădurea Dorna Candrenilor) Păd. la N de s. Dorna Candrenilor, în bazinul p. Ciotina (afl. dr. al r. Bistrița, la s. Iacobeni, com. Iacobeni, j. Suceava); (vechi) Ci o t in a Ca nd re n ilor. CERNAT, D. 234 (a. 2006).

3. P. pola r. Oron. (În sint. Runcul Dornei ${ }^{2}$ ) Ramificație a mt. Bîrnărel din masivul Giumalăului, la NV de or. Vatra Dornei. Tudose, B. 387 (a. 2012). $\diamond$ Cu ent. în funcție oron.: Muntele Runcul CHIRIȚĂ, D. 83 (a. 2003, harta). $\diamond$ Germ., cu invers. sint.: Dornj Runkut TTRM, $\mathrm{I}_{4}, 77 / 2$ (a. 1769). $\diamond \mathrm{Cu}$ ent. în funcție oron.: Runcul ib. (a. 1775).

a. P. pola r. ${ }^{+}$Oicon. (În sint.) Runcul Dornei [At. ca moșie la 1768: TTRM, $\mathrm{I}_{2}, 1011 / 2$.] Fost s., situat pe mt. Runc, în partea de NV a or. Vatra Dornei; (rar) Runcul Giumalău.

4. P. di fe r. ${ }^{+}$Oicon. (Germ., în comp.) Dorna Dinjoseni. [At. la 1774: ib. $\mathrm{I}_{1}, 619 / 1$.] Fost s. (considerat localit. compon. a s. Dorna IX) situat în aval de s. Dorna, în partea de N a s. Ortoaia, com. Dorna-Arini, j. Suceava. $\diamond$ Comp. rom., cu reducerea prep.: Dorna-Josenii ib. (a. 1848). $\downarrow$ Semicalc rus.: Nižna Dorna ib. $I_{2}, 1284 / 2$ (a. 1774).

5. P. dife r. ${ }^{+}$Oicon. (Germ., în comp.) Dorna-Pe Giumalău. [At. la 1790: ib. $I_{2}, 1011 / 2$.] Fost s. (considerat localit. compon. a s. Dorna IX) situat pe panta sudică a mt. Giumalău, la NV de or. Vatra Dornei. $\diamond$ Comp. rom., cu reducerea prep.: Dorna-Giumalău ib. (a. 1864).

6. P. d i fe r. Oicon. (În sint.) Șarul Dornei. a) [At. la 1774: ib. 1133/2.] S. (considerat localit. compon. a s. Dorna IX) numit astăzi Șarul Bucovinei, com. Şarul Dornei, j. Suceava. $\diamond$ Germ., în comp.: ŞarulDorna ib. 1134/1 (a. 1848).

b) [At. la 1838: ib.] S. (considerat localit. compon. a s. Dorna IX), com. Șarul Dornei, j. Suceava, format prin contopirea unei părți a s. Șarul cu o parte a s. Dorna, ambele rămase în Moldova, după ocuparea austriacă a Bucovinei. $\diamond$ Germ., în comp.: Dorna-Șarul ib. (a. 1833). $\diamond$ Cu elipsa determ.; vechi: Șarul ib. (a. 1774).

a. P. dife r. Oicon. (Rus., în sint.) M[alaja] Dorna [At. la 1774: ib. $\mathrm{I}_{1}, 367 / 1$.] S. neidentificat, prob. Poiana Ștampei, com. Poiana Ștampei, j. Suceava. $\diamond$ Rus., prin reducerea sint.: Dorna ib. I 4 , 202/2 (a. 1772).

b. P. difer. Oicon. (Germ., în sint.) Dorna Poienii [At. la 1855: ib. I2, 913/2.] S. Poiana Negrii (considerat localit. compon. a s. Dorna IX), com. Dorna Candrenilor, j. Suceava.

7. P. dife r. ${ }^{+}$Oicon. (Germ., în comp.) Dorna-Arșița [At. la 1778: ib. $\mathrm{I}_{1}, 21 / 1$.] Fost s. (considerat localit. compon. a s. Dorna IX), la NE de sbb. Argestrul a or. Vatra Dornei.

8. P. dife r. ${ }^{+}$Oicon. (Germ., în comp.) Dorna-Chilia [At. la 1899: ib. 221/1.] Fost s. (considerat localit. compon. a s. Dorna IX), în partea de $\mathrm{N}$ a or. Vatra Dornei. $\checkmark$ Cu reducerea comp.: Chilia ib. (a. $1896,1900)$. 
9. P. pola r. Oicon. (În comp.) Dorna-Arinii [At. la 1965: ib. 18/2.] S., com. Dorna-Arini, j. Suceava, format prin contopirea unei părți a s. Dorna $(\mathbf{I X})$, rămasă în Moldova după ocuparea austriacă a Bucovinei, cu s. Arinul din vecinătate; (vechi) Dorna Gurii Negre. $\diamond$ Prin reducerea comp.: Dorna ib. I 3 , 43/1 (a. 1799).

10. P. pola r. Oicon. (În sint.) Dorna Gurii Negre [At. la 1859: ib. $I_{1}, 366 / 2$.] (Vechi) Dorna-Arinii, com. Dorna-Arini, j. Suceava, format prin contopirea unei părți a s. Dorna (IX), rămasă în Moldova după ocuparea austriacă a Bucovinei, cu s. Gura Negrii. $\diamond$ În comp.: Dorna-Gura Negrii ib. (a. 1862).

11. P. d if e r. Oicon. (În der., cu ent. subînțeles) Dornişoara [At. la 1823: ib. $\mathrm{I}_{2}, 1285 / 1$.] S., com. Poiana Ștampei, j. Suceava, situat pe cursul superior al r. Dorna, în opoz. privat. cu s. Dorna (IX.1), situat în zona de vărsare a aceluiași curs de apă.

12. P. ext. Horon. (În perifr.; neofic.: Țara din Dorna) (Vechi) Țara Dornelor (X). IORGA, S.D. VI 2,4 (a. 1746).

- Patrion.: (IX.1) dorneni, sg. dornean TEZ. sUc. 232 (a. 1728, rez.), MDG, III, 195/2 (a. 1900), NALRdate, 48; germ. Dornaer TTRM, I3, 43/1 (a. 1779); Dornauer ib. (a. 1781); dorner ib. (a. 1641); magh. dornai ib.. (cca 1636); lat. Dornensis ib. (a. 1750); (IX.2) candreni, sg. candrean NALR-DATE, 25 sau căndreni, sg. căndrean CERNAT, D. 50 (a. 1818), NALR-DATE, 28; candrenari, sg. candrenar MOldovanu, s. 39 (a. 1979); dornacîndreni, sg. dornacîndrean ANCH.

- Pron.: (IX.1) Duórna NAlR-DATe, 45; Vátra Dórni ib. 47; (IX.2) Candréni ib. 45; (IX.9) Dórnaríni ib. 49.

- Scris și: (IX.2) Dorna-Căndreani tTrm, $I_{1}, 367 / 2$ (a. 1778); (IX.6) Dornașarul ib. $I_{1}, 367 / 1$ (a. 1833). - P. conf.: (I) Gura Durnei, DRH, A, VII, 726 (fals datat 1584, după slv.), p. anal. cu n. pers. Durnea. - Var.: (A) Apa Dorni BĂLAN, D.C. 31 (a. 1755), prin reducerea la -i a desin. dial. -ii a gen.; (IX.2) Dorna-Căndreni TTRM, $I_{1}, 367 / 2$ (a. 1896); Dorna Căndrenilor ib. (a. 1919); Dorna Cîndreni ib. (a. 1948), cu închiderea lui - $\breve{a}$ - sub infl. nazalei următoare; Dorna Cîndrenilor ib. (a. 1930); (IX.4) Dorna-Giosenii ib. 619/1 (a. 1848), cu păstrarea afric. mold. ğ ; (IX.10) Dorna-Gura Negrei ib. 367/1 (a. 1871), prin hipercor. morfologică; Dorna Gurei Negre ib. (a. 1859), prin hipercor. morfologică; (IX.5) Dorna-Pe Giumălău ib. $\mathrm{I}_{2}, 1011 / 2$ (a. 1896), cu închiderea la - $\breve{a}$ - a lui - $a$ - preton.; (A) Pîrăul Dorna grămadă, t. II, 527 (a. 1783), cu forma pop. a ent.; (IV) Piatra Dorni Bălan, D.c. 31 (a. 1755); (V) Runcul Dornii grămadă, T. II, 506 (a. 1768); (IX.6) Șarul Dornii tTRm, I 2 , 1134/1 (a. 1790). - Def. graf.: (IX.2) Dorna Candreilor ib. $I_{1}, 367 / 2$ (a. 1830); Dorna-Condreni ib. (a. 1924); (IX.5) Dorna-Gemeleu ib. I $2,1011 / 2$ (a. 1864); (IX.4) Dorna-Geosenei ib. $I_{1}, 619 / 1$ (a. 1859); Dorna-Giosănei ib. 619/2 (a. 1861); Dorna-Gioșeni ib. (a. 1864); (IX.5) Dornășarul ib. (a. 1833); (IX.9) Dornea ib. (a. 1846). (IX.6) Sarul Doamnei ib. I2, 1134/1 (a. 1889); Sarul Dorna ib. (a. 1864); Sarul Dornei ib. (a. 1925). - Translit.: (IX) Doma ib. I, $77 / 2$ (a. 1769); (IX.7) Dorna-Arsitza ib. $I_{1}$, 21/1 (a. 1778); (A) Dorna-Bach ib. $I_{3}, 42 / 2$ (a. 1776); (IX.2) Dorna-Candrarii ib. $I_{1}, 367 / 2$ (a. 1830); (IX.4) Dorna Dincosteny ib. 619/1 (a. 1781); Dorna Dinczosteny ib. (a. 1778); Dorna Dinsostenij ib. (a. 1785); Dorna Dinsostenj ib. (a. 1774); (IX.2) Dorna-Kandreni ib. $\mathrm{I}_{3}, 43 / 1$ (a. 1780); DornaKandrenj ib. $\mathrm{I}_{1}, 367 / 2$ (a. 1778); Dorna-Kandreny ib. $\mathrm{I}_{4}, 78 / 1$ (a. 1775); (VIII) Dorna Nyegrisora ib. 178/1 (a. 1781); (IX.5) Dorna-Pe Dzumaleu ib. I ${ }_{2}$, 1011/2 (a. 1862-1871); Dorna-Pe Schemeleu ib. (a. 1790); Dorna-Pe Tschemeleu ib. (a. 1790); (IX.6.b) Dorna Pojeneluj ib. I 2 , 914/1 (a. 1855); (IX.4) Dorna Susenj ib. I 4 , 78/1 (a. 1785); Dorna Sussaeny ib. (a. 1789); (IX.1) Dorna-Vatra Szarulj ib. $I_{4}, 78 / 1$ (a. 1774); Dorna Vatra Szatalui ib. (a. 1775); Dorna Vatra Szatuluj ib. (a. 1775); Dorna Vatra Szatuluy ib. (a. 1778); (IX.1) Dorna-Watra ib. $\mathrm{I}_{3}, 43 / 1$ (a. 1786); (A) Dornafluss ib. $\mathrm{I}_{3}, 42 / 2$ (a. 1781); (VIII) Dornaniegrisoara R[eu] ib. $\mathrm{I}_{4}, 178 / 1$ (a. 1788); (IX.9) Dorney ib. $\mathrm{I}_{3}, 43 / 1$ (a. 1799); (II) Dornisara ib. I4, $78 / 2$ (a. 1774); Dornisora ib. (a. 1775); (IX) Dorno ib. I 3 , 43/1 (a. 1780); (A) Dornu Fl[uss] ib. I4, 77/2 (a. 1788); Dorna Mare Reu ib. (a. 1781); Dorna Reu ib. (a. 1780); (II) Dornisora Reu ib. 78/2 (a. 1781); (V) Dornj Runkut ib. 77/2 (a. 1769); (I.1) Gura-Dorna ib. I 3 , 43/1 (a. 1640); (VI) Muntsei Dorni ib. I 4 , 77/2 (a. 1775); (IX.4) Nisch ib.. 78/1 (a. 1774); Nisch Dorna ib. (a. 1781); (IV.1) Piatra Dorna ib. (a. 1778); Piatra Dorni ib. (a. 1781); (IV) Piatra Dorniluj ib. 
77/2 (a. 1788); (IV.1) Piatra Dorny ib. 78/1 (a. 1789); (IV) Pietrille Dorni ib. 77/2 (a. 1775); (IV.1) Riatra Dorny ib. 78/1 (a. 1789); (IX.3) Runk ib. 77/2 (a. 1775); Runku ib. (a. 1775); (V) Runkul Dorni ib. (a. 1789); (IX.6) Sara-Dorna ib. I $\mathrm{I}_{2}, 1134 / 1$ (a. 1899); Saro Dornj ib. (a. 1774); Schara Dorna ib. (a. 1848); Șara Dorna ib. (a. 1900); (A, IX) Torna ib. I 3 , 42/2 (a. 1648), ib. 43/1 (a. 1717); (IX.1) Vatra Dorna ib. I 4 , 78/1 (a. 1775); Vatra Dorni ib. I 3 , 43/1 (a. 1779); Vatra Dorny ib. (a. 1849); Votra-Dorna ib. (a. 1849); Watra-Dorna ib. (a. 1849); Watra Dorni ib. (a. 1786).

- Etim.: (A) ent. dornă „bulboană, villtoare”, reflectînd caracteristica r. Bistriţa în aval de vărsarea r. Dorna (cf. MIHĂILESCU, D. 343), în funcție topon.

\section{Concluzii}

Stabilirea etimologiei toponimului Dorna confirmă necesitatea de a cunoaște întreg contextul extralingvistic în care intră acest nume. Posibilitatea de a fi interpretat atît ca toponim personal (cu originea întrun antroponim), dar și ca toponim descriptiv (cu originea într-un apelativ), obligă la verificarea ambelor ipoteze și la verificarea lor în cazul toponimelor sinonime sau similare. Prin acest demers s-au stabilit evoluțiile posibile pentru acest nume, ceea ce a presupus nu doar analiza lingvistică, ci și a situațiilor specifice fiecărui toponim în parte. Existența unor indicii sigure date de forma toponimului ar fi avut ca rezultat doar enumerarea acestora ca fiind niște cazuri similare. În situația de față a fost necesară reconstituirea trecutului acestora, pentru a se putea stabili posibilităţile reale de evoluție a formei toponimului și încadrarea toponimului vizat în seria ce ilustrează una dintre aceste posibilităţi. Atingerea acestui obiectiv a presupus atît analiza lingvistică, dar și a situaţiei concrete a realității (socio-)geografice desemnate, care trebuie să confirme problele strict lingvistice. Interferența lingvistică în cazul toponimelor conduce uneori la evoluții care nu pot fi întîlnite la nivelul vorbirii. În cazul de față, problemele de topică și morfologie au condus la sintagme a căror structură nu ar fi fost posibilă în cadrul limbii române.

\section{Bibliografie}

\section{A. Lucrări de referință}

Adumitroaei, M. \& Ciubotaru, M. (eds) (2013). Catagrafille Vistieriei Moldovei (1820-1845). V. Ținutul Hîrlău. Partea 1 (1820), Introducere de Mircea Ciubotaru, Demiurg Plus, Iași.

Bogrea, V. (1922). Gustav Weigand, XXVI-XXIX. Jahresbericht des Instituts für rumänische Sprache zu Leipzig, Leipzig 1921 (recenzie), în „Dacoromania”, II (1921-1922), p. 798-800.

Bolocan, G. (2009). Introducere la DELR, p. 3-10.

Conea, I. (1936). Din geografia istorică și umană a Carpaților. Nedei, păstori, nume de munți, în „Buletinul Societății Regale Române de Geografie", tom. LV, p. 42-117.

Conea, I. (1969). Toponimia și cercecarea toponimică în cadrul geografiei, în Îndrumător de cercetări geografice. Cercetări economico-geografice, Societatea de Științe Geografice, București, p. 243-247.

Conea, I. (2010). Clopotiva. Un sat din Hațeg, Editura Academiei, București; ed. I: 1940.

Conea, I. \& Bugă, D. (1971). Familia termenilor geografici din limba poporului român cu semnificația „un loc adînc într-o apă curgătoare”, în „Studii și cercetări de geologie, geofizică, geografie”, tomul XVI, nr. 1, p. 91-95.

Densusianu, Ov. (1915). Graiul din Țara Hațegului, Socec, București.

Iordan, I. (1963). Toponimia românească, Editura Academiei, București.

Mihăilescu, V. (1944). Țara Dornelor. Cadrul geografic și limitele aşezărilor, în C. Marinescu et al. (ed.), În amintirea lui Costantin Giurescu, București, p. 335-355.

Miklosich, F. (1927). Die Bildung der slavischen Personen und Ortsnamen, Carl Winters, Heidelberg.

Moldovanu, D. (1972). Principii ale lexicografiei toponimice, în „Anuar de lingvistică și istorie literară”, tom. XXIII, p. 73-100.

Moldovanu, D. (1991). Introducere to TTRM, $\mathrm{I}_{1}$, p. IX-LXXXII.

Moldovanu, D. (2005). Studiu monografic la TTRM, I4, p. IX-CXL.

Moldovanu, D. (2010). Teoria cîmpurilor toponimice, Editura Universității „Alexandru Ioan Cuza”, Iași.

Moldovanu, D. (2014). Introducere la TTRM, II 1 , p. VII-XXXII.

Petrovici, E. (1960). Toponimice slave de est pe teritoriul R.P.R. I. Toponimice prezentând $\boldsymbol{b}$ provenit din $\boldsymbol{g}$, în „Romanoslavica”, IV, p. 41-63.

Petrovici, E. (1970). Studii de dialectologie și toponimie, Editura Academiei, București. 
Prisacaru, A.-M. (2015). Toponimia românească din Bucovina habsburgică (actualele teritorii româneşti). Germanizare și reromânizare, Demiurg, Iași.

Suflețel, R. (1983). Aspecte dialectale ale toponimiei din Gorj, în R. Todoran et al. (ed.), Materiale și cercetări dialectale, II, ClujNapoca, 1983, p. 260-280.

Ștefulescu, A. (1909). Mânăstirea Tismana, Carol Göbl, București.

Werenka, D. (1895). Topographie der Bukowina zur Zeit ihrer Erwerbung durch Oesterreich (1774-1785), Cernăuți.

\section{B. Surse}

ANCH. $=$ Anchete (directe și indirecte), 1966-1984.

ATLAS MOLD. = Institutul Geografic al Armatei, Atlasul Moldovei (sc. 1:50000), București, 1892-1898.

BĂLAN, D.C. = Bălan, T., Noui documente câmpulungene, Tipografia „Mitropolitul Silvestru”, Cernăuți, 1929.

CADE = Candrea, I.-A. \& Adamescu, Gh., Dicționar enciclopedic ilustrat, Editura „Cartea Românească”, București 1982.

CERnAt, D. = Cernat, I., Dorna Candrenilor, satul de la poalele Ouşorului (Pagini de monografie), Editura Pim, Iași, 2008.

CHIRIȚĂ, D. = Chiriță, V., Depresiunea Dornelor. Studiu fizico-geografic, Editura Universității din Suceava, Suceava, 2003.

DELR = Bolocan, Gh. et al., Dicționarul entopic al limbii române, I, Editura Universitaria, Craiova, 2009.

DLR = Dicționarul limbii române (ediție anastatică), Editura Academiei, București, 2010.

DRH, A = Documenta Romanie Historica. A. Moldova, Editura Academiei, București, 1975-2014.

Dтв = Goicu, V. \& Suflețel, R., Dicționarul toponimic al Banatului, vol. III, D-E, Tipografia Universității din Timișoara,

Timișoara, 1986.

DTG = Eremia, A., Dicționar explicativ și etimologic de termeni geografici, Știința, Chișinău, 2006.

DTRO = Dicționarul toponimic al României. Oltenia, (coordonator: Gh. Bolocan), Editura Universitaria, Craiova, 1995.

GABOR, D. = Gabor, I., Dicționarul comunităților catolice din Moldova, Editura Conexiuni, Bacău, 1996.

GRĂMADĂ, T. = Grămadă, N., Toponimia minoră a Bucovinei, I-II, Editura Anima, București, 1996.

HARTA MIL. = Harta R.S. România, executată de Direcția Topografică Militară, sc. 1:25.000, București, 1962.

HURM. = E. de Hurmuzaki (ed.), Documente privind istoria românilor, vol. XV, Acte și scrisori din arhivele orașelor ardelene

(Bistrița, Brașov, Sibiu), Partea I, 1358-1600, Socec, București, 1911.

IORGA, S.D. = Iorga, N., Studii și documente cu privire la istoria românilor $\left(\mathrm{VI}_{2}\right)$, Socec, București, 1904.

MDG $=$ Marele dicționar geografic al României, I-V, Editura Socec, București, 1898-1902.

MDTM = Tezaurul toponimic al României. Moldova, volumul II, Mic dicționar toponimic al Moldovei. Structural și etimologic,

Partea 1. Toponime personale, (coordonator: D. Moldovanu), Editura Universității „Alexandru Ioan Cuza”, Iași, 2014.

MIHĂIlesCu, D. = Mihăilescu, V., Țara Dornelor. Cadrul geografic și limitele așezărilor, în C. Marinescu et al. (ed.), In amintirea lui Costantin Giurescu, București, 1944, p. 335-355.

Moldovanu, s. = D. Moldovanu, Sufixul $-A R I(p l$. lui $-A R)$ in toponimia românească. Origine, funcționalitate, dinamică, în „Anuarul de lingvistică și istorie literară”, tom. XXVII, 1979-1980, p. 21.

NALR-DATE = Noul Atlas Lingvistic al României. Moldova şi Bucovina. Date despre localități și informatori, Editura Academiei, București, 1987.

SĂNDUlACHE, B. = Săndulache, I., Relieful bazinului hidrografic Bistricioara, Editura Cetatea Doamnei, Piatra-Neamț, 2009. SD = Scriban, A., Dicționaru limbii românești, Iași, 1939.

TEZ. suc. = Direcția Generală a Arhivelor Statului din Republica Socialistă România, Din tezaurul documentar sucevean. Catalog de documente, 1393-1849 (întocmit de Vasile Gh. Miron, Mihai Ștefan Ceaușu, Gavril Irimescu, Sevastița Irimescu), Serviciul de publicații și valorificare din Direcția generală a Arhivelor Statului, București, 1983.

TTRM = Tezaurul toponimic al României. Moldova (coordonator: D. Moldovanu). $\mathrm{I}_{1-2}$, Repertoriul istoric al unităților administrativ-teritoriale (1772-1988), Editura Academiei, București, 1991-1992. I3, Toponimia Moldovei în documente scrise în limbi străine (exclusiv slavona), Editura Universităţii „Alexandru Ioan Cuza”, Iaşi, 2004. I 4 , Toponimia Moldovei în cartografia europeană veche (cca 1395-1789), Editura Universității „Alexandru Ioan Cuza”, Iași, 2005.

Tudose, B. = Tudose, D., Munţii Bistriței. Toponimie, Editura Pim, Iași, 2012. 


\section{Abrevieri}

\begin{tabular}{|c|c|c|}
\hline to & $=$ & anul; anii \\
\hline abrev. & $=$ & abreviere, abreviat \\
\hline acc. & $=$ & accentuat $(\breve{a})$ \\
\hline adj. & $=$ & adjectiv; adjectival( $(\breve{a})$ \\
\hline afl. dr. & $=$ & afluent de pe partea dreaptă \\
\hline afl. st. & $=$ & afluent de pe partea stângă \\
\hline fric. & $=$ & africată \\
\hline pel. & $=$ & apelativ(e) \\
\hline t. & $=$ & $\operatorname{articol;}$ articulat $(\breve{a})$ \\
\hline it. & $=$ & atestare; atestat $(\breve{a})$ \\
\hline om. & $=$ & comuna \\
\hline omp. & $=$ & compus \\
\hline ompon. & $=$ & component $(\breve{a})$ \\
\hline lef. graf. & $=$ & deformări grafice \\
\hline er. & $=$ & $\operatorname{derivat}(\breve{a})$ \\
\hline lescr. & $=$ & $\operatorname{descriptiv}(\breve{a})$ \\
\hline esin. & $=$ & desinență \\
\hline leterm. & $=$ & determinant \\
\hline lial. & $=$ & dialect; dialectal $(\breve{a})$ \\
\hline & $=$ & est \\
\hline echipol. & $=$ & echipolentă (opoziție) \\
\hline ent. & $=$ & (termen) entopic \\
\hline etim. & $=$ & etimologie \\
\hline etimol. & $=$ & etimologic $(\breve{a})$ \\
\hline fiton. & $=$ & fitonim \\
\hline gen. & $=$ & genitiv \\
\hline geogr. & $=$ & (termen) geografic (savant) \\
\hline germ. & $=$ & germană; germanic \\
\hline hidron. & $=$ & hidronim \\
\hline hipercor. & $=$ & hipercorecție \\
\hline hodon. & $=$ & hodonim \\
\hline horon. & $=$ & horonim \\
\hline ib. & $=$ & ibidem \\
\hline infl. & $=$ & influență \\
\hline invers. & $=$ & inversiune \\
\hline izv. & $=$ & izvorul \\
\hline j. & $=$ & județul \\
\hline lat. & $=$ & latină; latinesc \\
\hline & $=$ & localitate(a) \\
\hline & & maghiară; maghi \\
\hline
\end{tabular}

\begin{tabular}{|c|c|c|}
\hline mold. & $=$ & moldovenesc \\
\hline mt. & $=$ & muntele \\
\hline $\mathrm{N}$ & $=$ & nord \\
\hline n. pers. & $=$ & nume de persoană \\
\hline neofic. & $=$ & neoficial; neoficializat \\
\hline nom. & $=$ & nominativ \\
\hline ofic. & $=$ & oficial; oficializat $(\breve{a})$ \\
\hline oicon. & $=$ & oiconim \\
\hline opoz. & $=$ & opoziție \\
\hline or. & $=$ & oraşul \\
\hline oron. & $=$ & oronim; oronimic $(\breve{a})$ \\
\hline p. & $=$ & pârâul \\
\hline p. anal. & $=$ & prin analogie \\
\hline p. conf. & $=$ & prin confuzie \\
\hline p. difer. & $=$ & prin diferențiere \\
\hline p. difer. omon. & $=$ & prin diferențiere omonimică \\
\hline p. ext. & $=$ & prin extensiune \\
\hline p. polar. & $=$ & prin polarizare \\
\hline patrion. & $=$ & patrionim; patrionimic $(\breve{a})$ \\
\hline păd. & $=$ & pădurea \\
\hline perifr. & $=$ & perifrază; perifrastic $(\breve{a})$ \\
\hline pl. & $=$ & plural \\
\hline pop. & $=$ & popular $(\breve{a})$ \\
\hline pron. & $=$ & pronunție; pronunțat \\
\hline r. & $=$ & râul \\
\hline rus. & $=$ & rusă; rusesc \\
\hline$S$ & $=$ & sud \\
\hline s. & $=$ & sat(ul) \\
\hline schimb. & $=$ & schimbare \\
\hline sint. & $=$ & sintagmă \\
\hline slv. & $=$ & slavonă; slavonesc \\
\hline ss. & $=$ & sate(le) \\
\hline terit. & $=$ & teritoriu \\
\hline top. & $=$ & toponim \\
\hline topon. & $=$ & toponimic $(\breve{a})$ (funcție) \\
\hline trad. & $=$ & traducere \\
\hline translit. & $=$ & transliterație; transliterații \\
\hline $\mathrm{V}$ & $=$ & vest \\
\hline var & $=$ & variantă; variante \\
\hline vf. & $=$ & vârful \\
\hline
\end{tabular}

